\title{
Assessment of Climate Change Awareness and Risk Perception Among Rural People in Funtua Local Government Area, Katsina State, Nigeria
}

\author{
Abdulrahman Isah Hazo', Bulus Ajiya Sawa1, Mamman Musa² \\ 1Department of Geography and Environmental Management, Faculty of Physical Sciences, \\ ${ }^{1}$ Ahmadu Bello University, Zaria, Nigeria \\ 2Department of Science Education, Faculty of Education, Ahmadu Bello University, Zaria, Nigeria
}

\begin{abstract}
Climate change has become the dominant topic of discourse among scientists and other stakeholders in climate science in this century. Several researches have been conducted to assess its magnitude, causes, adverse impacts and possible solution to its challenges at various scales; where adaptation and mitigation were the fundamental recommendations. While public awareness and perception of the change, are the necessary pre-requisites to achieve true adaptation and mitigation, in the context of sustainable development. However, most of the negotiations were made at international level (making it Top-Down affair) with little regard to national dynamics of individual countries. The aim of this research was to assess the level of awareness and risk perception of climate change, among rural people in Funtua Local Government Area, Katsina State, Nigeria. A household questionnaire survey method was used in collecting the primary data from 384 randomly selected respondents, in which $97.7 \%$ response rate was recorded. Descriptive statistics such as frequency and percentage distribution, mean score and tables were used in analyzing and presenting the data. While Binomial Logistic Regression Analysis was used to ascertain the effect of some socio-demographic characteristics of the respondents, on their likelihood of been aware of climate change and perceiving it as a risk. The study revealed that climate change awareness was impressively high (78\% of the respondents) were aware of it, though with poor knowledge of its causes among the respondents. While majority (73\%) of the respondents agreed that climate change is a great risk to their individual lives and the society. The study further revealed that, sex, level of educational attainment, and main occupation of the respondents $(\mathrm{p}<.005)$ significantly predicts their level of climate change awareness. But, only level of education and main occupation $(\mathrm{p}<.005)$ significantly predicts risk perception of the adverse change among the respondents. The study then recommended that, the Governments should tailored their climate change policy and programmes, toward educating the rural people, so as to enhance their level of awareness of the scenario for better participation in adaptation and mitigation programmes; the Government (at both federal and state levels) through their relevant agencies, should double their effort in public awareness campaign, especially on causes and the risk associated with climate change to the rural people; that, extension agencies should double their efforts in public awareness campaign about climate change and adaptation techniques to especially those engaged in climate-sensitive activities; and that further study should be conducted to assess adaptive capacity and adaptation strategies adopted among the rural people.
\end{abstract}

KEYWORDS: Climate Change, Awareness, Risk perception, Predictors.

\subsection{INTRODUCTION}

Climate change stands as the greatest challenge facing our planet in this century, which must be recognized as a global issue of extreme concern [1]. Despite some few skeptical views (such as [2] and [3], there exists a widespread consensus among individual scientists and institutions (e.g. [4]; [5]; [6] and [7]) that climate change is real, likewise its impacts, and it is the greatest environmental threat to sustainable development in this century. Indeed, various systems (such as agriculture, biodiversity, water resources and human health) have already started paying the price of the changes, though at different magnitudes in different parts of the world [8]. According to ref [9], climate change is defined as a change in the mean of temperature, precipitation and wind pattern that persists for an extended period of typically decades or longer. That is, it is a statistically significant deviation or shift from the average weather condition of climatic elements, which persist for several decades or longer.

Therefore, now that the climate is changing is no longer the issue, but how to address the challenges it poses, mitigation and adaptation are the important proposed options by many scientists and institutions. However, literature on adaptation and mitigation (such as [10] \& [6]) made it clear that, public awareness and risk perception of the scenario are very important and necessary pre-requisites for true adaptation anywhere in the world. This is because, our perception about something, often determine our action/reaction to it, as [11] rightly put it that:

\section{"If you don't know you are at risk, you are even more at risk, because you may not be taking the necessary preventive and/or adaptation measures".}

Ref [12] and [13] observed that most of the researches dealing with climate change are based on principles and theories of climatology, mostly focused on regional and national assessments, with little or no recourse to traditional knowledge of the local/rural communities, making most of their findings less useful at local levels. This is because, different communities are affected by the change differently; as a result they deal with different aspects of the scenario, depending on where they live. As such, communities (particularly rural) in many cases accumulates some useful 
information at the grass root level (regarding changes in the environment) which have been neglected for a long time in policy formulation and implementation [14].

Several studies related to climate change awareness and/or risk perception among people have been conducted at different scales and in different parts of the world. For instance, [15] conducted a research on assessment of public climate change awareness and risk perception in the world, using 2007-2008 Gallup World Poll Data collected from 195,000 randomly selected, nationally representative samples in 119 countries. The study revealed that the level of climate change awareness is generally low and unevenly distributed globally, with the highest level recorded in the developed countries, whereas developing countries had extremely low awareness. However, the study revealed that more people perceive the change as a great threat to them in developing than in developed countries; with level of educational attainment stands as the strongest and most common predictor of both awareness and risk perception of the change across the globe.

In the same vein, [16] undertook a study to assess climate change awareness and perception amongst the inhabitants of Muscat governorate, Oman, using questionnaire survey method.

The study revealed that climate change awareness is fairly high among people of the area, despite some limitations in their knowledge of its causes, prevention or adaptation measures. The study also revealed that gender and income level were the most significant predictors of climate change awareness in the study area. [17] and [18] in their studies revealed that climate change awareness was relatively high amongst individuals in their study area, with type of occupation and age respectively as the strongest predictor of climate change awareness. In Nigeria, [19] assessed farmers' awareness, vulnerability and adaptation to climate change in Adamawa state, Nigeria. The study revealed that majority of the respondents are aware of climate change, and opined that it affects them negatively. The study also revealed that age, educational level, years of farming experience and beliefs about the causes of climate change were the major drivers of awareness in the study area. Critical to the above literature is that none of them took a micro-scale spatially, and were not conducted in the same study area as with this study. Therefore, this study assessed awareness and perception of the risk associated with climate change among rural people in Funtua Local Government Area, Katsina State, Nigeria.

\subsection{THE STUDY AREA}

Funtua is a Local Government Area (LGA) in Katsina State, Nigeria. It is situated in the extreme southern part of the state, at about $197 \mathrm{~km}$ from Katsina city (the state capital) and $72 \mathrm{~km}$ from Zaria in Kaduna State. It is located between latitudes $11^{\circ} 19^{\prime} 59^{\prime \prime} \mathrm{N}$ and $11^{\circ} 42^{\prime} 58^{\prime \prime} \mathrm{N}$, and longitudes 7014'42"E and 7029'15"E, (Figure 1.1). It is bordered to the south by Giwa L.G.A of Kaduna State; to the west by Dandume, to the north by Faskari, and to the east by Bakori and Danja L.G.As of Katsina State. It covers an area of approximately $448 \mathrm{~km}^{2}$. In terms of climate, the study area belongs to the tropical continental (wet and dry) climatic zone of northern Nigeria, classified as Aw in Koppen's climatic classification. It is characterized by short wet and long dry seasons, with very high annual temperature range ([20]Otegbeye, 2004). Specifically, the annual rainfall of the study area varies froms $900 \mathrm{~mm}$ to $1,200 \mathrm{~mm}$, with a single maximum (usually in the month of August), while the annual average minimum and maximum temperatures are $19^{\circ} \mathrm{C}$ and $32^{\circ} \mathrm{C}$ respectively [21]. However, climate of the study area varies considerably according to months and seasons, due to the effects of two air masses (i.e warm and moist Tropical maritime $(\mathrm{mT})$ air mass, which originates from Atlantic ocean, and the relatively cool and dry Tropical continental (cT) air mass, which originates from the Sahara desert [22]; [23]. The seasons are a cool, dry and dusty (Harmattan) season from November to February; a hot - dry season from March to early April; a warm - wet season from late April to June; and a less marked cold - wet season from July to early October, which shows steady decreasing rainfall and gradual lowering of temperatures [24]. Vegetation of the area is the Sudan Savanna type, which combines characteristics of both Guinea and Sahel Savanna [21]. Relief of the study area is composed of undulating plain (part of the high plains of Hausa-land) which generally rises up to about $600-700 \mathrm{~m}$ above sea level, intersected by series of hills, which are important hydrological centres that control drainage system of the area, which is dominated by mostly seasonal rivers and streams. The major land use in the area are residential, crops cultivation (mostly rain-fed) and to some extent irrigation along rivers, streams and reservoirs, animal rearing (both intensive and extensive systems) Other occupations of the people include trading, as well as fishing along rivers, streams and reservoirs [25].

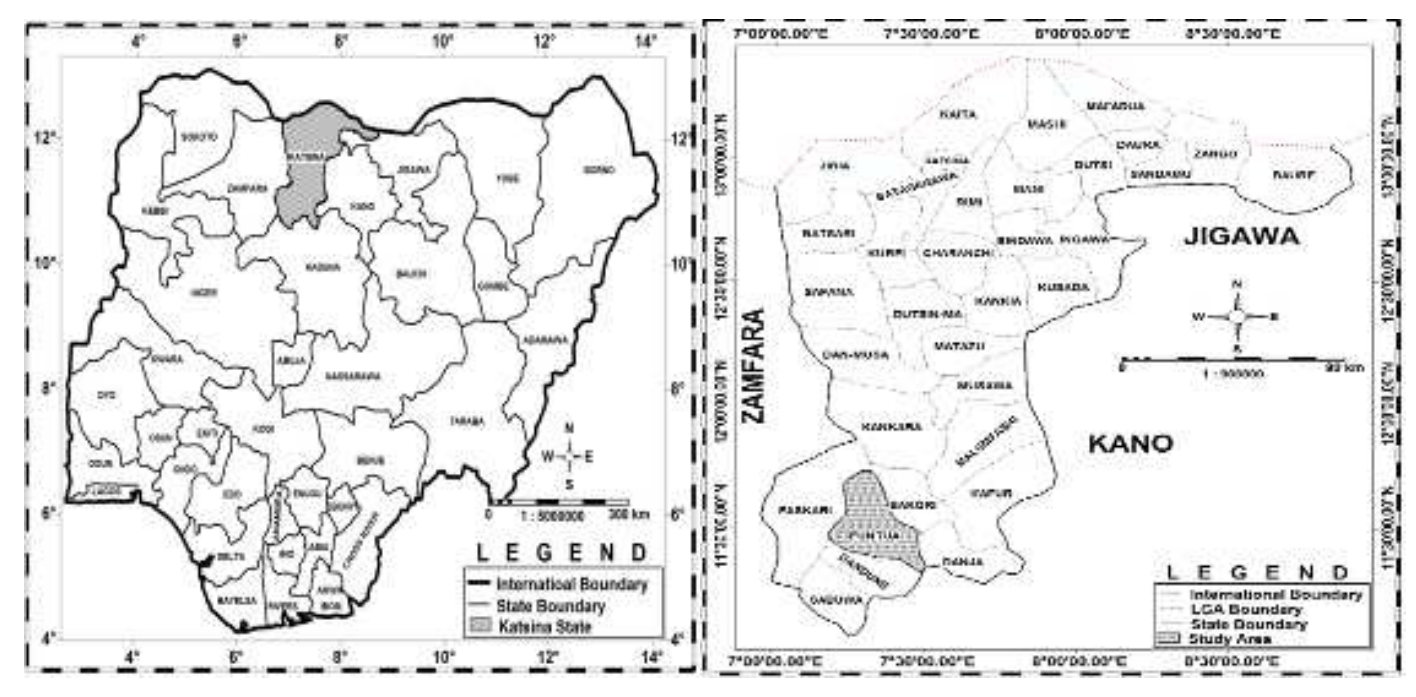




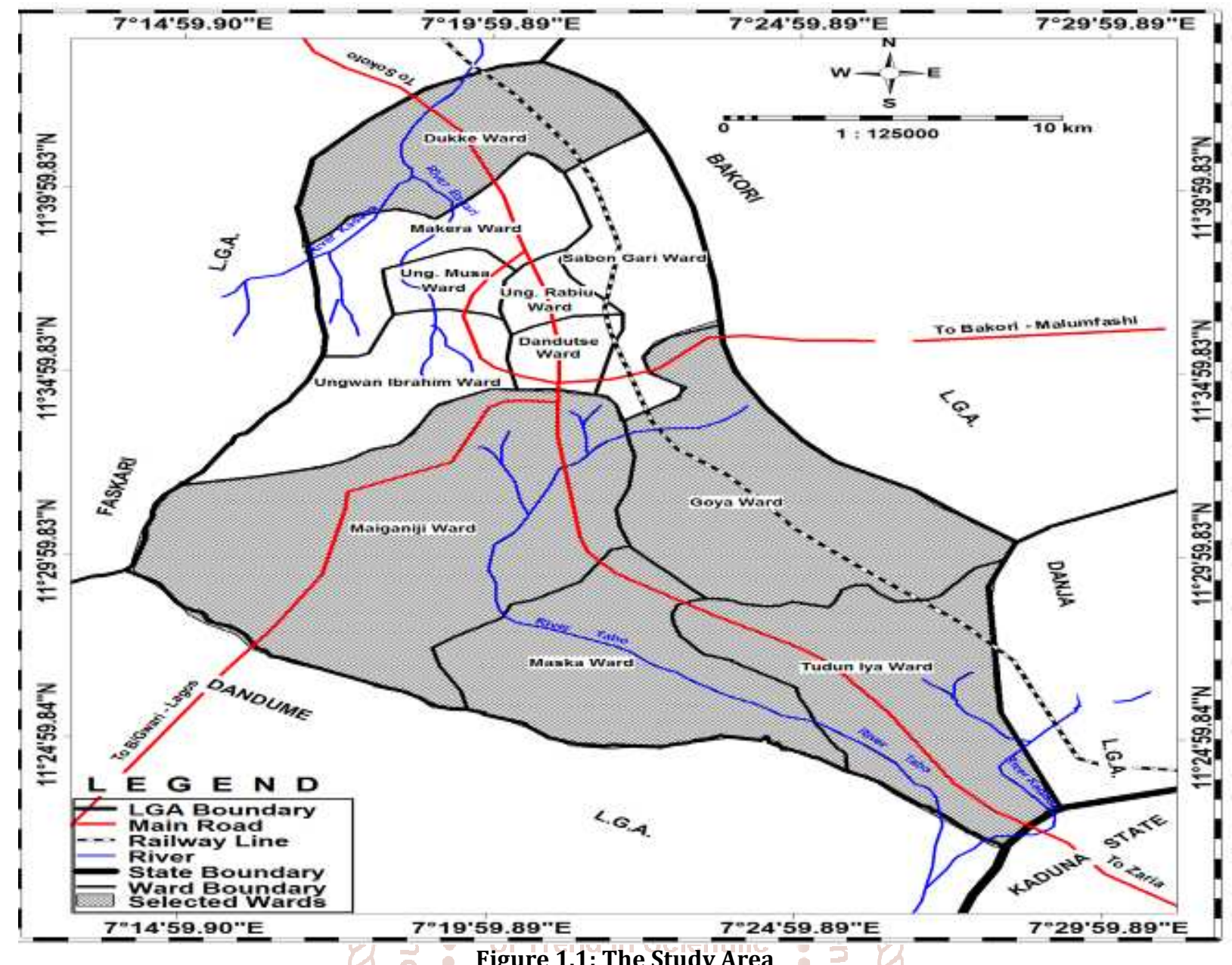

\section{Source: Modified from Administrative Map of Katsina State, (2016)}

\subsection{MATERIALS AND METHODS}

To achieve the aim of this study, the following data were collected using household questionnaire survey. These are:

1. Data on some basic socio-demographic characteristics of the respondents;

2. Data on the respondent's awareness and perception of the risk associated with climate change.

A multi-stage sampling technique was used in selecting the respondents for this research. The first stage involved removal of the urban wards in the study area; while the rural wards (i.e. Dukke, Goya, Maigamji, Maska and Tudun-Iya) were purposively selected.

The second stage involves selection of the settlements, from each of the selected wards (by arranging all settlements under each of the rural wards in alphabetical order), and every forth count was systematically selected, which yielded a total of twelve (12) settlements.

Then, a sample size of 382 respondents was determined using [26] method, based on the total projected population of the selected wards (as at 2015); which was shared to the selected wards proportionate to their projected population, using [27] method. While the proportion obtained for each ward was then distributed evenly among the selected settlements that make up that ward, due to the absence of population figure at the settlement level.
Then, the last stage involve the selection of household heads from each of the selected settlements, which was done with the help of community heads ('mai-unguwa') and other volunteers, based on convenience.

A total of 382 copies of a structured questionnaire were purposively administered to sampled household heads who are at least forty (40) years old and are resident of the study area for at least 30 years, in which 95.6\% (366 copies) response rate was recorded.

The data were analyzed using descriptive statistics (such as frequency count, percentage and mean score (weighted mean $\mathrm{W} \bar{X}$ ), presented in tables. The weighted mean is given as:

$$
w \bar{x}=\frac{\Sigma X_{1} \times W_{1}+X_{2} \times W_{2} \ldots \ldots X_{n} \times W_{2}}{\Sigma X}
$$

Where: $\mathrm{X}=$ is the frequency of respondents for each of the Lickert's five points; $\mathrm{W}=$ is the weight for each of the Lickert's five points (5, 4, 3, 2 and 1$)$ in this case; $\sum X=$ is the total frequency. Mean score values of $\leq 3.0$ were considered insignificant and a value $>3.0$ considered significant. While binomial logistics regression analysis was used, to ascertain the effects of socio-demographic characteristics of the respondents, on their likelihood of been aware of climate change and perceiving it as a real risk, using SPSS 23 software package. 


\subsection{RESULTS AND DISCUSSIONS}

\subsubsection{Socio-Demographic Characteristics of the Respondents}

Table 1 presents a summary of the Socio-Demographic Characteristics of the Respondents. It shows that majority of the respondents (74\%) were males, while female respondents constituted only $26 \%$. In terms of age, the table shows that majority of the respondents (an aggregate of $72 \%$ ) are at least 50 years old, and only $28 \%$ are within the age group of 40 to 49 years. While their level of educational attainment, the result shows that the highest level of education most of the respondents had is secondary school (47.8\%), $21.3 \%$ attended only primary school, while those who had up to tertiary education accounted for $6.6 \%$, and the remaining $24.3 \%$ had no formal education at all. In terms of occupational distribution, it shows that, the most dominant occupation among the respondents is farming (48.9\%). Others are: fishing (14.8\%), civil servant (12.3\%), trading $(11.7 \%)$, animal rearing $(6.8 \%)$, then craft and others (such carpenters, tinkers, brick layers e.t.c. were $5.5 \%$.

Table 1: Summary of Socio-Demographic Characteristics of the Respondents

\begin{tabular}{|c|c|c|c|c|}
\hline Characteristics & Variables & Frequency & Percentage & Mean \\
\hline \multirow{3}{*}{ Sex } & Male & 271 & 74 & \\
\hline & Female & 95 & 26 & \\
\hline & Total & 366 & 100 & \\
\hline \multirow{4}{*}{ Age } & $40-49$ years & 103 & 28 & \\
\hline & $50-59$ years & 174 & 48 & 54 \\
\hline & $\geq 60$ years & 89 & 24 & \\
\hline & Total & 366 & 100 & \\
\hline \multirow{5}{*}{ Level of education } & No formal education & 89 & 24.3 & \\
\hline & Primary & 78 & 21.3 & \\
\hline & Secondary & 175 & 47.8 & \\
\hline & Tertiary & 24 & 6.6 & \\
\hline & Total $n t h$ & 366 & 100 & \\
\hline \multirow{7}{*}{ Occupation } & Farming & 179 & 48.9 & \\
\hline & Fishing & 54 & 14.8 & \\
\hline & Lumbering & 25 & 6.8 & \\
\hline & Trading & 43 & 11.7 & \\
\hline & Inte Civil service $\mathrm{Ou}$ & mall 45 & 12.3 & \\
\hline & Craft \& others & tific 20 & 5.5 & \\
\hline & Total & 366 & 100 & \\
\hline \multirow{5}{*}{ Estimated annual income } & $\leq \mathrm{N} 150,000$ & 193 & 53 & \\
\hline & $150,001-300,000$ & 820 & 22 & 202,664 \\
\hline & $300,001-450,000$ & 40 & 11 & \\
\hline & $\geq 450,001$ & 51 & 14 & \\
\hline & Total & 366 & 100 & \\
\hline \multirow{5}{*}{ Years of residency in the area } & $30-39$ & 61 & 16.7 & \\
\hline & $40-49$ years & 42 & 11.5 & \\
\hline & 50-59 years & 174 & 47.5 & 52 \\
\hline & $\geq 60$ years & 89 & 24.3 & \\
\hline & Total & 366 & 100 & \\
\hline
\end{tabular}

Source: Data Analysis (2017)

The table further shows the estimated annual income of the respondents (in Nigerian Naira). Majority (53\%) estimated their annual incomes as $\leq \mathrm{N} 150,000$ and $22 \%$ put it at $\mathrm{N} 150,001$ to 300,000 , and $11 \%$ are between $\mathrm{N} 300,001$ and 450,000 , while $14 \%$ estimated their income to $\geq \mathrm{N} 450,001$. In terms of years of residency in the study area, the results revealed that most of the respondents (47.5\%) have been living within the study area for between 50 and 59 years, while $24.3 \%, 11.5 \%$ and $16.7 \%$ are those who have been living in the area for $\geq 60$ years, 40 to 49 years and 30 to 39 years respectively.

The implication of the distribution to this study is that, information collected from such a predominantly males, elderly and fairly educated population, with majority engaged in climate-sensitive activities (particularly agriculture) and residents of the area for a long period of time is of great relevance. This is because, such a population must have accumulated large volume of experience about the environment (that is the climate).

\subsubsection{Climate Change Awareness among the Respondents}

The result of climate change awareness among the respondents is presented in Table 2. It shows that majority (78\%) opined that they are aware of climate change, while the remaining $22 \%$ claimed not aware of the change.

Table 2: Climate Change Awareness among the Respondents

\begin{tabular}{|c|c|c|c|}
\hline S/No & Awareness & Frequency & Percentage \\
\hline 1 & Aware & 285 & 78 \\
\hline 2 & Not Aware & 81 & 22 \\
\hline & Total & 366 & 100 \\
\hline
\end{tabular}

Source: Author's Analysis (2017)

The high level of climate change awareness may not be unconnected to the fact that majority of the respondents are engaged in climate-sensitive economic activities (particularly agriculture). This is in agreement with the 
findings of [19] and [28], in which they all found a high level of climate change awareness among people of their respective study areas. However, a closer look at this result, revealed that the percentage of those who are not aware of the change were substantial (22\%) as such, there is still long way to go with programmes and policies that will enhance the rural people's awareness of the phenomenon, for better advocacy and implementation of adaptation and mitigation programmes to the adverse change.

\subsubsection{Sources of Climate Change Information among the Respondents}

Table 3 presents the result on main sources of climate change information among the respondents. These include electronic media (Radio, Television etc.), print media (Newspaper, Magazine etc.), extension agents, friends/relatives and other sources.

Table 3: Sources of Climate Change Information among the Respondents

\begin{tabular}{|c|c|c|c|}
\hline $\begin{array}{c}\text { S/ } \\
\text { No }\end{array}$ & $\begin{array}{c}\text { Source of } \\
\text { information }\end{array}$ & Frequency & Percentage \\
\hline 1 & Electronic Media & 237 & 64.8 \\
\hline 2 & Prints Media & 10 & 2.7 \\
\hline 3 & Extension Agents & 61 & 16.6 \\
\hline 4 & Friends/Relatives & 53 & 14.5 \\
\hline 5 & Others & 5 & 1.4 \\
\hline & Total & $\mathbf{3 6 6}$ & $\mathbf{1 0 0}$ \\
\hline
\end{tabular}

Source: Author's Analysis, (2017)

It revealed that majority (64.8\%) of the respondents claimed that electronic media (particularly Radio broadcast) is their main source of information about the change, $16.6 \%$ had extension agents as their main source, $14.5 \%$ said friends or relatives are their main source, print media $2.7 \%$, and only $1.4 \%$ opined other sources. A closer examination of the distribution revealed that an aggregate of $84.1 \%$ of the respondents relied on a relatively 'refined' source of climate change information, as any information coming from the media or extension agents usually have scientific backings. This finding is in agreement with that of [19] and [29], where the researchers found out that electronic media (particularly Radio) were the major source of climate change information among people of their study areas. Therefore, the possible implication of this is that, adoption of policies and programmes meant for adaptation, will be faster among such population with some background information about the adverse change than their odds.

\subsubsection{Perceived Causes of Climate Change among the Respondents}

Result of the perceived causes of climate change among the respondents is given in Table 4. It shows that, the most significantly perceived causes of climate change among the respondents are: destruction of nature and its resources $(\bar{x}=4.17)$, increased burning of fossil fuels $(\bar{x}=3.95)$, increased use of chemicals $(\bar{x}=3.87)$ and community disobeying God $(\bar{x}=3.89)$. Others are industrial pollution $(\bar{x}=3.41)$ and neglect of our traditional values $(\bar{x}=3.08)$. The perception "community disobeying God" could be attributed to the fact that, the people are predominantly followers of the two dominant Abrahamic monotheism of Islam and Christianity.
Table 4: Perceived Causes of Climate Change among the Respondents

\begin{tabular}{|c|l|c|c|}
\hline $\begin{array}{c}\text { S/ } \\
\text { No }\end{array}$ & \multicolumn{1}{|c|}{ Cause } & $\begin{array}{c}\text { Mean } \\
\text { Score } \\
(\bar{x})\end{array}$ & Rank \\
\hline 1 & Community Disobeying God & $3.89^{*}$ & 4 \\
\hline 2 & $\begin{array}{l}\text { Neglect of our Traditional } \\
\text { Values }\end{array}$ & $3.08^{*}$ & 6 \\
\hline 3 & $\begin{array}{l}\text { It is Caused by Natural } \\
\text { Factors Only }\end{array}$ & 1.11 & 7 \\
\hline 4 & $\begin{array}{l}\text { Destruction of nature and its } \\
\text { Related Resources (eg. } \\
\text { Deforestation) }\end{array}$ & $4.17^{*}$ & 1 \\
\hline 5 & Increased use of chemicals & $3.87^{*}$ & 3 \\
\hline 6 & $\begin{array}{l}\text { Increased burning of fossil } \\
\text { fuels }\end{array}$ & $3.95^{*}$ & 2 \\
\hline 7 & Industrial pollution & $3.41^{*}$ & 5 \\
\hline 8 & Oil spillage & 0.34 & 8 \\
\hline
\end{tabular}

*Significantly Perceived Causes among the Respondents Source: Author's Analysis (2017)

While the majority that opined destruction of nature and its related resources is in line with the findings of [29] and [17]. For instance, [17] found out that deforestation, overgrazing and bush burning for various economic uses, were the significantly perceived factors causing climate change among respondents of their study.

A close examination of this result revealed that the rural people have a very good idea of the anthropogenic causes of climate change, which is in line with $[6,9 \& 10]$, all of which proved that increased burning of fossil fuels, destruction of nature and use of chemicals (due to increased industrialization, urbanization and population boom) across the globe were the main causes of climate change.

However, there is still long way to go by, especially for those who attributed the change to supernatural causes (e.g. community disobeying God and traditional neglect.

\subsubsection{Perceived Impacts of Climate Change among the Respondents}

The perceived impacts of climate change among the respondents is presented in Table 5. The result shows that, the most significantly perceived impact of climate change among the respondents was shortage of water and its related resources (mean score $[\bar{x}]=4.10$ ). This is in line with the projection by ref [30] that, many countries in Sub-Saharan Africa would face water shortage fromnow on (not because of lower rainfall) but pollution and destruction of water systems, due to frequent floods. Decrease in crops yield is the next significantly perceived impact of the change among the respondents $(\bar{x}=4.08)$; which agrees with the findings of [28] and [13], where they all found out that decrease in crops yield were significantly perceived as the impact of climate change in Dutsin-ma LGA of Katsina and in Kaduna State respectively. Others include frequent cropsfailure $(\bar{x}=$ $3.89)$, frequent dry spells during rainy season $(\bar{x}=3.78)$, increased sickness due to extreme heat conditions $(\bar{x}=3.76)$. Decrease in vegetation and pasture resources $(\bar{x}=3.56)$, rural - urban migration of youth $(\bar{x}=3.36)$, increased crops/livestock infestation and diseases ( $\bar{x}=3.33)$, and increased poverty $(\bar{x}=3.32)$ were also significantly perceived as the impacts of climate change among the 
respondents. All other impacts were insignificantly perceived in the study area

\begin{tabular}{|c|c|c|c|}
\hline S/No & Statement & $\begin{array}{l}\text { Mean } \\
\text { Score } \\
\end{array}$ & Rank \\
\hline 1 & $\begin{array}{l}\text { It leads to frequent crops } \\
\text { failure in recent times }\end{array}$ & $3.89 *$ & 3 \\
\hline 2 & $\begin{array}{c}\text { It leads to decreased in crops } \\
\text { yield }\end{array}$ & $4.08 *$ & 2 \\
\hline 3 & $\begin{array}{c}\text { Increased crops and } \\
\text { livestock infestation \& } \\
\text { diseases }\end{array}$ & $3.33^{*}$ & 8 \\
\hline 4 & Insufficient food supply & 2.73 & 11 \\
\hline 5 & Increase in cost of food crops & 2.84 & 10 \\
\hline 6 & $\begin{array}{c}\text { Shortage of water and its } \\
\text { related resources }\end{array}$ & $4.10 *$ & 1 \\
\hline 7 & $\begin{array}{l}\text { Reduction in vegetation and } \\
\text { pasture resources }\end{array}$ & $3.56^{*}$ & 6 \\
\hline 8 & Rural-urban migration & $3.36^{*}$ & 7 \\
\hline 9 & $\begin{array}{l}\text { Increased poverty among } \\
\text { people }\end{array}$ & $3.32^{*}$ & \\
\hline 10 & $\begin{array}{l}\text { Increase sickness due to } \\
\text { extreme heat conditions }\end{array}$ & $3.76^{*}$ & \\
\hline 11 & $\begin{array}{c}\text { Frequent flooding during } \\
\text { rainy season }\end{array}$ & 2.37 & $12^{-}$ \\
\hline 12 & $\begin{array}{c}\text { Frequent dry spell during } \\
\text { rainy season }\end{array}$ & $3.78 *$ & \\
\hline
\end{tabular}

*Significantly Perceived Impacts among the Respondents Source: Author's Analysis (2017)

\subsubsection{Predictors of Climate Change Awareness among the Respondents}

Result of the Binomial logistic regression analysis, conducted to ascertain the effects of socio-demographic characteristics (sex, age, level of education, occupation and income) on the likelihood of being aware of climate change among the respondents is presented in table 5.

It shows that the model significantly fits the data, $p>0.05$ (Hosmer and Lemeshow test), with 67.5\% predictive power (Nagelkerke test); while it classified $89.9 \%$ of the variance in climate change awareness among the respondents. The coefficient for the logistic regression model is statistically significant $(211.355, d f=14, p<0.05)$, which indicates significant difference.

However, cross examination of the significance and predictive power of the five explanatory variables shows that sex, level of education and main occupation (all $p$-values $<0.05$ ), significantly added to the variation in climate change awareness among the respondents, while age $(p>0.05)$ and income $(p>0.05)$ are not.

However, going by this result, it can be concluded that sex, level of educational attainment and main occupation are the significant predictors of climate change awareness among rural people in the study area. This is in line with the findings of [17], [16] and [15], who respectively revealed main occupation, sex and level of education as the significant predictors of climate change awareness in their study area. Therefore, for the rural people to better adapt to climate change (which is a function of their level of awareness per se), there is urgent need to improve their level of educational attainment, particularly among those who engaged in climate sensitive economic activities (crops cultivation, animals rearing, and fishing among others).

Table 5: Predictors of Climate Change Awareness among the Respondents

\begin{tabular}{|c|c|c|c|}
\hline Variable & Wald Test & $\bar{B}$ & Odds Ratio \\
\hline Constant & .065 & .215 & 1.240 \\
\hline Sex $($ Base $=$ Female $)$ & 41.782* & & \\
\hline Sex (1) Males & & $2.730^{*}$ & 15.329 \\
\hline Age (Base $=30$ to 49 years) & .640 & & \\
\hline Age (1) 50 to 59 years & & .061 & 1.063 \\
\hline Age $(2) \geq 60$ years & & .396 & 1.486 \\
\hline Education (Base $=$ No formal education) & $18.586 *$ & & \\
\hline Education (1) Primary & & $1.311^{*}$ & 3.709 \\
\hline Education (2) Secondary & & $1.880^{*}$ & 6.555 \\
\hline Education (3) Tertiary & & $2.761^{*}$ & 15.816 \\
\hline Occupation (Base $=$ Farming) & 46.722* & & \\
\hline Occupation (1) Fishing & & $-1.791^{*}$ & .167 \\
\hline Occupation (2) Lumbering & & $-1.840^{*}$ & .159 \\
\hline Occupation (3) Trading & & $-2.899 *$ & .055 \\
\hline Occupation (4) Civil service & & $-3.907^{*}$ & .020 \\
\hline Occupation (5) Craft and others & & $-5.377^{*}$ & .005 \\
\hline Income (Base $\leq \mathbb{N}-150,000)$ & 3.108 & & \\
\hline Income (1) N-150,001-300,000 & & .220 & 1.247 \\
\hline Income (2) $\mathrm{N}-300,001-450,000$ & & 1.055 & 2.872 \\
\hline Income $(3) \geq \mathbf{N}-450,001$ & & .083 & 1.086 \\
\hline Hosmer \& Lemeshow test of model fitness & & $4.705,(8) p>0.05$ & \\
\hline Classification Power & & $89.9 \%$ & \\
\hline Nagelkerke pseudo $\mathbf{R}^{2}$ & & $67.5 \%$ & \\
\hline Model coefficient $X^{2}$ & & $211.355,(14) p<0.005$ & \\
\hline
\end{tabular}

Source: Author's Analysis (2017) 


\subsubsection{Risk Perception of Climate Change among the Respondents}

The result of the respondents' risk perception of climate change is presented in Table 6, which classified the respondents into agreed, disagreed and those who were neutral to the statements that climate change poses great risk them and their respective communities. Majority (73\%) of the respondents agreed to the statement that climate change poses great risk to them and their communities, $14 \%$ disagreed to the statement, while the remaining $14 \%$ were neutral and are categorically not sure of whether the change poses any risk or not.

Table 6: Perception of the Risk Associated with Climate Change among the Respondents

\begin{tabular}{|c|c|c|c|}
\hline $\begin{array}{c}\text { S/ } \\
\text { No }\end{array}$ & $\begin{array}{c}\text { Climate Change } \\
\text { Poses Great Risk }\end{array}$ & Frequency & Percentage \\
\hline $\mathbf{1}$ & Agree & 267 & 73 \\
\hline $\mathbf{2}$ & Undecided & 48 & 13 \\
\hline $\mathbf{3}$ & Disagree & 51 & 14 \\
\hline & Total & $\mathbf{3 6 6}$ & $\mathbf{1 0 0}$ \\
\hline
\end{tabular}

Source: Author's Analysis, (2017)

The possible implication of the distribution is that, adaptation and mitigation, policies and programmes will be adopted and implemented easier and faster among such a population with majority perceiving the change as a great risk; which in line with the findings of [15].

\subsubsection{Predictors of Climate Change Risk Perception among the Respondents}

Result of the Binomial Regression Analysis conducted to ascertain the effect of sex, age, level of education, occupation and income on the likelihood of perceiving climate change as a risk among the respondents is presented in Table 7.

Table 7: Predictors of Climate Change Risk Perception among the Respondents

\begin{tabular}{|c|c|c|c|}
\hline Variable & Wald Test & $B$ & Odds Ratio \\
\hline $\begin{array}{l}\text { Constant } \\
\text { Sex (Base = Female) } \\
\text { Sex (1) Males } \\
\text { Age (Base = } 30 \text { to } 49 \text { years) } \\
\text { Age (1) } 50 \text { to } 59 \text { years } \\
\text { Age (2) } \geq 60 \text { years } \\
\text { Education (Base = No formal education) } \\
\text { Education (1) Primary } \\
\text { Education (2) Secondary } \\
\text { Education (3) Tertiary } \\
\text { Occupation (Base = Farming) } \\
\text { Occupation (1) Fishing } \\
\text { Occupation (2) Lumbering } \\
\text { Occupation (3) Trading } \\
\text { Occupation (4) Civil service } \\
\text { Occupation (5) Craft and others } \\
\text { Income (Base } \leq \mathbb{N}-150,000 \text { ) } \\
\text { Income (1) } \mathrm{N}-150,001-300,000 \\
\text { Income (2) } \mathrm{N}-300,001-450,000 \\
\text { Income (3) } \geq \mathrm{N}-450,001 \\
\text { Hosmer \& Lemeshow test of model fitness } \\
\text { Classification Power } \\
\text { Nagelkerke pseudo } \mathrm{R}^{2}\end{array}$ & $\begin{array}{l}.813 \\
\text { din } \mathrm{Sc} \\
\mathbf{4 1 . 2 6 1}\end{array}$ & $\begin{array}{l}.088 \\
396 \\
1.520 \\
1.699 \\
2.558 \\
-1.837 \\
-1.902 \\
-2.569 \\
-4.743 \\
-4.296 \\
\\
.310 \\
1.114 \\
.0912 \\
4.705 \text {, (8) } p=0.480 \\
92 \% \\
62 \%\end{array}$ & $\begin{array}{l}1.306 \\
1.033 \\
1.301 \\
2.507 \\
4.390 \\
13.616 \\
.157 \\
.162 \\
.028 \\
.031 \\
.029 \\
1.206 \\
2.771 \\
1.090\end{array}$ \\
\hline Model coefficient $X^{2}$ & & $167.84,(14) p<0.000$ & \\
\hline
\end{tabular}

Source: Author's Analysis (2017)

It revealed that the model was a good fit of the data $p=0.480$ (Hosmer and Lemeshow test), and explained $62 \%$ of the variation (Nagelkerke $\mathrm{R}^{2}$ test), while it classified $92 \%$ of the log-likelihood. It also revealed a significant difference in risk perception among people of different socio-demographic background (the model coefficient) 167.84, $d f=14, p=.000$. Level of education $(p<0.05)$ and main occupation $(p<0.05)$ significantly added to the prediction of climate change risk perception among the people, while age, sex and income (all $p$-values $>0.05$ ). This corroborates with the findings of [ $15 \&$ 17] who found out that level of education and main occupation respectively as the strongest predictors of climate change risk perception in their respective studies.

\subsection{SUMMARY, CONCLUSION RECOMMENDATIONS}

It is no longer a matter of doubt, that climate change is real, likewise its impacts on bio-physical and socioeconomic systems (directly or indirectly) though, it manifest at different magnitudes in different part of the world. Therefore, this study sought to assess climate change awareness and risk perception (as the most important prerequisite for taking both adaptation and mitigation measures) among rural people in Funtua LGA, Katsina State, Nigeria. 
The study revealed that climate change awareness was fairly high (78\%), with electronic media (particularly radio) as the main source of information about the change among the rural people in the study area. While majority attributed climate change to destruction of nature and its related resources, increased burning of fossil fuels, increased use of chemicals and community disobeying God.

Climate change awareness differs significantly among rural people of different socio-demographic background in the study area $(p<0.05)$, while sex, level of education and main occupation are the significant predictors of climate change awareness among the people. However, majority of the people (as opined by 73\% of the respondents) perceived climate change as a great risk, while the risk perception significantly differs among the rural people with different socio-demographic background $(p<0.05)$. Level of educational attainment and main occupation are the significant predictors of climate change risk perception among the rural people.

Thus, the study concluded that both climate change awareness and risk perception was impressively high among rural people in the study area, which will makes adoption and implementation of adaptation and/or mitigation measures much easier and faster among such a population. Since we only takes adaptation or mitigation measures to what are aware of and perceived it as a risk.

The study recommended that:

1. the Government (at both federal and state level) should be tailored their climate change policy and programmes, toward educating the rural people, so as to enhance their level of awareness of the scenario for better participation in adaptation and mitigation programmes;

2. The Government, (at both federal and state levels) through their relevant agencies, should double their effort in public awareness campaign, especially on causes and the risk associated with climate change to the rural people;

3. That, extension agencies should double their efforts in public awareness campaign about climate change and adaptation techniques to especially those engaged in climate-sensitive activities;

4. that further study should be conducted to assess adaptive capacity and adaptation strategies adopted among the rural people.

\section{REFERENCES,}

[1] Adebayo, A.A and Oruonye, E.D (2013). An Assessment of Climate Change in Taraba state, Nigeria. Nigerian Journal of Tropical Geography, 4(2): 602 - 612.

[2] Frank, P. (2008). A Climate of Belief: The Claim that Anthropogenic Carbon dioxide (CO2) is Responsible for the Current Warming of the Earth's Climate is Scientifically Unsupportable, Because Climate Models are Unreliable. Skeptic, 14(1), 22 - 30.

[3] Washington, H. and Cook, J. (2011). Climate Change Denial: Head in the Sand. London: Earth-Scan, pp 43 46.

[4] Stern, N. (2008). The Economics of Climate Change: $A$ Review. Accessed from http://www.hm-reviewreport.cf. Retrieved on the 21st January, 2016.
[5] Mings, L. (2008). Determination of Knowledge, Attitude and Practices on Climate Change Issue: Environmental Tourism Consulting, 4(7) pp33 - 37.

[6] Intergovernmental Panel on Climate Change [IPCC], (2007a). Climate Change 2007. Impacts, Vulnerability and Adaptation. Parry, M. L., Carizian, O. F., Palutikof, J. P., Vander, L., Paul, J. AND Hanson, C. (Eds): Contribution of Working Group II to the Fourth Assessment Report of the IPCC. Cambridge University Press, Cambridge; UK.

[7] UNDP (2009). Linking Climate Change Policies to Human Development Analysis and Advocacy. A Guidance for Human Development Report Teams.

[8] McCarthy, J. J. and White, K. S. (2001). Climate Change 2001: Impacts, Adaptation and Vulnerability. Third Assessment Report, IPCC Working Group3: Cambridge University Press, Cambridge.

[9] IPCC, (2007b). Special Report on Regional Impacts of Climate Change. Summary for Policy Makers. Retrieved from http://www.ipcc-wg1-ucar.edu/wg1/wg1report.htm.Accessed on 05th September, 2015.

[10] UNFCCC, (2006). Application of Environmentally Sound Techniques for Adaptation to Climate Change. UNFCCC Technical Paper, 2006.

[11] Leiserowitz, A.A. (2015). Climate Change Adaptation and Mitigation: The Role of Public Awareness and Risk Perception in for Planning and Implementation. An Exclusive Interview, Published online by Reuters International $17^{\text {th }}$ November, 2015.

[12] Oladipo, E. (2011). The challenge of climate change for Nigeria: An overview. In Iguisi, E.O; Ati, O.F; Yusuf, R.O \& Ubogu, A.E (Eds.), Climate Change Impacts: Risks and Opportunities, Lead Presenter (2), 22 - 44. Proceedings of the International Conference of the Nigerian Meteorological Society, held at NAERLS Conference Hall, Ahmadu Bello University, Zaria-Nigeria, 13th to 17 th November, 2011.

[13] Abaje, I.B (2016). Assessment of Rural Communities' Perception, Vulnerability and Adaptation Strategies to Climate Change in Kaduna State, Nigeria. An Unpublished Ph. D. Thesis, Department of Geography, Ahmadu Bello University Zaria, Nigeria.

[14] Stoot, P. A. and Kettleborough, J. A. (2002). Origin and Estimate of Uncertainty in Predictions of the $21^{\text {st }}$ Century Temperature Rise. Nature 416:723-726.

[15] Tien, M.L, Ezra, M.M, Peter, D.H, Cia-Ying, K., and Leiserowitz, A.A. (2015). Predictors of Climate Change Awareness and Risk Perception around the World. Nature Climate Change: (5): 1014-1020. Doi: http://dx.doi.org/10.1039/nclimate2728.

[16] Al-Buloshi, A.S. and Ramadan, E. (2015). Climate Change Awareness and Perceptions Amongst the Inhabitants of Muscat Governorate, Oman. American Journal of Climate Change, (4):330-336. Doi: http://dx.doi.org/10.4236/ajcc.2015.44026. Accessed on $10^{\text {th }}$ Nov., 2015.

[17] Hasan, Z. and Akhtar, S. (2011). Determinants of Public Awareness and Attitude on Climate Change in Urban Bangladesh: Dhaka as a Case. European Journal of Scientific Research: 4(7), 124 - 138. 
[18] Khan, S., Ul-Hassan, M. and Aslam, M. (2012). People's Perceptions about Climate Change and Adaptation in the Arid Region of Pakistan. A Paper Submitted to the Second World Sustainability Forum, 1 - 30 November, 2012.

[19] Adebayo, A. A., Onu, J. I., Adebayo, E. F. and Anyanwu, S. O. (2012). Farmer's Awareness, Vulnerability and Adaptation to Climate Change in Adamawa State, Nigeria. British Journal of Arts and Social Sciences, 9(2), 104-115. Retrieved http://www.bjournal.co.uk/BJASS: Accessed 23 ${ }^{\text {rd }}$ January, 2016.

[20] Otegbeye, G.O. (2004). Drought and Desertification: Challenges and Afforestation in Arid and Semi-Arid Regions. Savana, 19(1):1-11. ABU, Zaria-Nigeria.

[21] Abaje, I. B., Abdullahi, N. and Jeje, O. G. (2016). Climate Change and Infectious Diseases in Funtua L.G.A of Katsina State, Nigeria. Afr. J. Online, 5(1), 47 - 58.

[22] Sawa, B.A. (2002). Trends in the Temporal Variability of Occurrence of Wet and Dry Spells North of Latitude $10^{\circ} \mathrm{N}$ in Nigeria. Zaria Geographer, 1(5): 34-41. Department of Geography, ABU, Zaria-Nigeria.

[23] Ayoade, J.0. (2004). Climate Change: An Overview. Ibadan. Vantage Publishers Ltd, pp. 45-66.

[24] Abaje, I.B. (2007). Introduction to Soils and Vegetation. Kafanchan: Personal Touch Productions, (Chapter8), 25 $-39$.
[25] Lawal, T. M. (2009). Funtua: A History of Maska and Funtua Districts. Kano, Alfikra Publication Ventures Nigeria Limited.

[26] Krejcie, R. V. and Morgan, D. W. (1970). Determining Sampled Size for Research Activities. Educational and Psychological Measurements. Pp 30, 607 - 610.

[27] Yamane, T. (1967). "Statistics": An Introductory Analysis". 2nd Edition, New York: Harper \& Row.

[28] Abaje, I. B., Sawa, B. A. and Ati, O. F. (2014). Climate Variability and Change, Impacts and Adaptation Strategies in Dustin-ma Local Government Area of Katsina State, Nigeria. Journal of Geography and Geology, 6(2), 103 - 112: Canadian Centre of Science and Education. http://dx.doi.org/10.5539/jgg.v6n2p103.

[29] Egbe, C. A., Yaro, M. A., Okon, A. E. and Bisong, F. E. (2014). Rural People's Perception to Climate Variability and Change in Cross River State, Nigeria. Journal of Sustainable Development, 7(2), 25 - 36. DOI:dx.doi.org/10.5539/jsd.v7n2p25.

[30] Union of Concerned Scientists (UCS) (2011). Global Warming Effects around the World. Accessed from www.ucs-international.info.org/html. Retrieved on $3^{\text {rd }}$ November, 2015. 